\title{
CAMPUR KODE PEMAKAIAN BAHASA DI LINGKUNGAN SMP NEGERI 8 BENGKULU TENGAH
}

\author{
'Ana Herlina; ${ }^{2}$ Rokhmat Basuki; ${ }^{3}$ Suryadi \\ ${ }^{123}$ Program Sudi Pendidikan Bahasa Indonesia FKIP Universitas Bengkulu
}

Abstrak

\section{Korespondensi: herlinaana2107@gmail.com}

Tujuan penelitian ini untuk mendeskripsikan wujud campur kode dan mendeskripsikan faktor yang melatarbelakangi campur kode di lingkungan SMP Negeri 8 Bengkulu Tengah. Metode yang digunakan dalam penelitian ini adalah metode deskriptif dengan pendekatan kualitatif. Teknik yang digunakan dalam pengumpulan data adalah teknik simak bebas libat cakap (SBLC), teknik rekam dan angket/kuesioner. Langkah-langkah analisis data terdapat lima tahap yaitu, (1) transkripsi data, (2) pengkodean data, (3) klasifikasi data, (4) analisis data dan (5) penyimpulan. Hasil analisis data penelitian ditemukan bentuk campur kode tingkat kata dan struktur frasa serta klausa. Campur kode bentuk tingkat kata yaitu bahasa Rejang, bahasa Melayu Bengkulu, bahasa Inggris dan bahasa Jawa. Campur kode bentuk struktur yaitu (a) struktur frasa bahasa Rejang dan bahasa Jawa. (b) Strukur klausa yaitu bahasa Rejang. Faktor-faktor yang melatarbelakangi terjadi campur kode yakni sikap penutur atau nonkebahasaan dan kebahasaan.

Kata Kunci: Campur Kode, Komunikasi, Lingkungan Sekolah.

\section{Abstract}

The purpose of this research is to describe the form of code mixing and to describe the factors behind the code mix in SMP Negeri 8 Bengkulu Tengah. The method used in this research is descriptive method with a qualitative approach. The techniques used in data collection are free engagements (SBLC), record techniques and questionnaires. There are five steps in data analysis, namely, (1) data transcription, (2) data coding, (3) data classification, (4) data analysis and (5) conclusion. The results of the analysis of research data found mixed forms of wordlevel codes and phrase structures and clauses. Mix word-level form codes namely Rejang, Bengkulu Malay, English and Javanese. Mix the structure code, which is (a) the phrase structure of the Rejang and Javanese languages. (b) The clause structure, which is the Rejang language. Factors underlying the mixed code occur are the attitude of the speaker or non-linguistic and linguistic.

Keywords: Code Mix, Communication, School Environment

\section{PENDAHULUAN}

Bahasa merupakan sistem komunikasi paling efektif untuk mengungkapkan pemikiran, baik bentuk lisan maupun tulisan, baik berupa ide, penemuan, pendapat, inspirasi, maupun perasaan. Dengan bahasa, manusia dapat berinteraksi, bersosialisasi, dan berkomunikasi antara satu sama lain sehingga mampu menjadi bagian dari masyarakat. Oleh sebab itu, bahasa tidak pernah lepas dari setiap aktivitas dan kehidupan manusia. 
Dalam penggunaannya, bahasa dipengaruhi oleh faktor linguistik dan faktor non linguistik (Chaer,2004:21). Faktor non linguistik yang sangat berpengaruh adalah faktor sosial. Hal inilah yang menjadikan kajian bahasa dengan faktor sosial sangat menarik. Setiap masyarakat memiliki nilai-nilai sosial dan budaya khususnya dalam penggunaan bahasa sehingga antarkelompok masyarakat dapat berbeda-beda. Penggunaan bahasa di lingkungan SMP Negeri 8 Bengkulu Tengah bisa terjadi pada situasi formal dan situasi informal. Penggunaan bahasa situasi formal dalam lembaga pendidikan misalnya pemakaian bahasa yang terjadi di ruang kelas, ruang guru dan ruang TU. Dalam lembaga pendidikan pemakaian bahasa formal/resmi yaitu bahasa Indonesia yang sudah diatur dalam UU no 24 tahun 2009 pasal 29 ayat 1 yang berbunyi " bahasa Indonesia wajib digunakan sebagai bahasa pengantar dalam pendidikan nasional". Wujud dalam mengembangkan bahasa Indonesia yaitu dengan pemerintah menetapkan bahasa Indonesia sebagai mata pelajaran yang wajib dipelajari di setiap jenjang pendidikan. Penggunaan bahasa dalam situasi informal ini bisa terjadi pada situasi komunikasi yang lebih santai seperti di kantin, di teras kelas, di halaman sekolah maupun di parkiran.

Masyarakat tutur memiliki berbagai variasi atau ragam bahasa yang digunakan masyarakat dalam berkomunikasi sehingga pemilihan ragam bahasa tersebut sangat dipengaruhi latar belakang sosial, budaya, dan situasi (Chaer,2004:61). Saat ini, sebagian besar masyarakat Indonesia dapat disebut sebagai masyarakat multilingual atau dwibahasa. Kedwibahasaan atau yang dikenal dengan istilah bilingualisme dapat didefinisikan sebagai suatu kemampuan individu dalam menguasai dua bahasa dalam komunikasinya. Kedwibahasaan dipandang sebagai wujud dalam suatu peristiwa kontak bahasa. Suwito (1983:40) menyatakan bahwa istilah kedwibahasaan merupakan istilah yang pengertiannya bersifat nisbi atau relatif. Mackey (dalam Aslinda dan Syafyahya,2007:68), menyatakan bahwa dalam membicarakan kedwibahasaan tercakup beberapa pengertian, seperti masalah tingkat, fungsi, pertukaran/alih kode, percampuran/campur kode, interferensi, dan integrasi.

Campur kode adalah percampuran serpihan-serpihan bahasa berupa kata, frasa, dan klausa suatu bahasa ke dalam bahasa lain yang digunakan (dalam Chaer, 2004:114). Nababan (1991:32), ciri yang menonjol dalam peristiwa campur kode adalah kesantaian atau situasi informal. Jadi, campur kode umumnya terjadi saat berbicara santai, sedangkan pada situasi formal hal ini jarang sekali terjadi. Apabila dalam situasi formal terjadi campur kode, hal ini disebabkan tidak adanya istilah yang merujuk pada konsep yang dimaksud. Seperti telah disebutkan bahwa kode dapat berupa idiolek, dialek, register, tindak tutur, ragam, dan registrasi, maka unsur-unsur yang bercampur pun dapat berupa varian bahasa maupun bahasa itu sendiri.

Berdasarkan konsep mengenai campur bahasa dapat dinyatakan kembali bahwa campur kode merupakan penggunaan atau pemakaian dua bahasa atau lebih dalam situasi tertentu. Pemakaian dua bahasa atau lebih ini dapat berwujud kata, frasa, klausa, ungkapan, dan idiom. Pemakaian hal-hal tersebut bertujuan menimbulkan gaya terhadap sebuah tuturan. Gaya atau cara yang digunakan dihubungkan dengan wujud campur kode, dan membatasi wujud campur kode tersebut terhadap situasi dan tidak lagi menduduki fungsi-fungsi sendiri.

Adapun unsur-unsur kebahasaan campur kode (dalam Suwito, 1983:78-80), dibedakan menjadi 6 yaitu (a) penyisipan unsur-unsur yang berwujud kata, (b) frasa, (c) bentuk baster, (d) perulangan kata, (e) ungkapan atau idiom dan (f) klausa. Adapun faktor 


\section{Ana Herlina}

pendorong terjadinya campur kode dapat dibedakan atas latar belakang sikap (atitudinal type) atau nonkebahasaan dan latar belakang kebahasaan (linguistic type).

Relevansi penelitian tentang campur kode yaitu (1) Angga Saputra (2015) dengan judul Campur Kode pada Kata Sambutan Acara Resepsi Pernikahan Masyarakat Serawai. Dengan hasil penelitian adalah bentuk campur kode yang terjadi berupa campur kode kata, frasa, dan klausa. Faktor yang melatarbelakangi terjadinya campur kode dikarenakan kebiasaan penutur dengan mitra tutur dalam berkomunikasi dan faktor sosial dari segi pendidikan penutur dalam bersosialisasi. (2) Intan Febrina Mayang Sari (2016) dengan judul Kajian Alih Kode dan Campur Kode Dalam Tuturan Masyarakat Kelurahan Jalan Baru Kecamatan Curup kota Kabupaten Rejang Lebong. Dengan hasil penelitian yang menyebutkan bahwa bentuk alih kode dan campur kode terjadi karena adanya faktor yang mempengaruhinya bahasa penutur itu sendiri dan faktor sosial yang mengharuskan penutur beralih kode dan campur kode. (3) Adi Nugroho (2011) dengan judul Alih Kode dan Campur Kode Pada Komunikasi Guru-Siswa di SMA Negeri 1 Wonosari Klaten. Hasil penelitian berupa bentuk alih kode meliputi dua segi yakni segi bahasa dan hubungan antar bahasa (bahasa Perancisbahasa Indonesia. Bentuk campur kode meliputi unsur sintaksis dan kategori kata. Faktor yang mempengaruhi alih kode dan campur kode yakni hubungan penutur dan mitra tutur, perubahan topik pembicaraan dan hadirnya orang ketiga. (4) Pungki Nugroho (2012) dengan judul Analisis Penggunaan Alib Kode dan Campur Kode Pada Guru Babasa Indonesia di SMP Negeri 2 Mantingan. Hasil penelitian yakni alih kode berwujud alih bahasa mencakup alih kode ekstern dan alih kode intern, sedang campur kode berwujud penyisipan partikel, kata, gabungan partikel dan kata, frasa dan klausa. Faktor yang melatarbelakangi alih kode yakni perubahan situasi pembicaraan situasi formal ke informal atau sebaliknya, kebiasaan guru menggunakan bahasa Jawa, sedangkan campur kode dilatarbelakangi oleh kesalahan tuturan guru dan ketidaksadaran guru.

Berdasarkan latar belakang yang telah dideskripsikan, menjadi landasan penulis untuk melakukan penelitian mengenai campur kode. Untuk itu, peneliti bermaksud untuk melakukan penelitian berjudul Campur Kode Pemakaian Babasa di lingkungan SMP Negeri 8

Bengkulu Tengah. Rumusan masalah yang diuraikan sebagai berikut:

1. Bagaimana bentuk campur kode yang terjadi dalam pemakaian bahasa di lingkungan SMP Negeri 8 Bengkulu Tengah?

2. Apa saja faktor yang melatarbelakangi campur kode dalam pemakaian bahasa di lingkungan SMP Negeri 8 Bengkulu Tengah?

\section{METODE}

Metode penelitian ini menggunakan metode penelitian deskriptif. Lokasi penelitian ini di SMP Negeri 8 Bengkulu Tengah Kecamatan Pematang Tiga Kabupaten Bengkulu Tengah. Data dalam penelitian ini adalah tuturan guru, pegawai, dan siswa-siswi SMP Negeri 8 Bengkulu Tengah berupa campur kode yaitu penyisipan kata, frasa, klausa, perulangan kata, idiom dan baster dan faktor yang melatarbelakangi. Sumber data penelitian ini adalah guru, staf, dan siswa-siswi SMP Negeri 8 Bengkulu Tengah. Teknik yang digunakan dalam pengumpulan data adalah simak bebas libat cakap (SBLC), rekam dan angket/ kuesioner. Langkah-langkah analisis data dalam penelitian ini adalah Transkripsi data, Pengkodean data, Klasifikasi data, Analisis data dan Penyimpulan data. 


\section{HASIL DAN PEMBAHASAN}

\section{Hasil}

Berdasarkan hasil penelitian di SMP Negeri 8 Bengkulu Tengah diperoleh wujud campur kode berupa kata, frasa dan klausa serta faktor yang melatarbelakangi campur kode yaitu kebahasaan, sikap penutur atau non kebahasaan, kebiasaan dan ketidaksadaran guru.

\section{Pembahasan}

\section{A. Kata}

Campur kode berbentuk kata yang dimaksud adalah unsur kata dari bahasa yang masuk dalam bahasa sumber. Campur kode kata terdiri atas beberapa bahasa yakni bahasa Rejang, bahasa Indonesia, bahasa Inggris dan Jawa.

Campur kode kata dalam bahasa Rejang ke dalam bahasa Indonesia pada komunikasi di lingkungan SMPN 8 Bengkulu Tengah. Bentuk campur kode kata dalam bahasa Rejang yang ditemukan penulis dalam percakapan $\mathbf{I}$.

Percakapan I, Komunikasi ini terjadi pada tanggal 15 Juli 2019, pukul : 09.20 WIB di ruang TU dengan topik syarat-syarat pendaftaran. Ibu Leni adalah staff TU di SMPN 8 Bengkulu Tengah berumur 31 tahun sehari-hari menggunakan bahasa Rejang. Orang tua murid berusia 30 tahun, sehari-hari menggunakan bahasa Rejang. Data (II/1) (I/3) mengenai orang tua murid bertanya keberadaan pak Rudi (wakil kepala sekolah) dan data (II/2) (I/9) mengenai orang tua murid memberikan kelengkapan syarat pendaftaran siswa baru. Data berikut merupakan bentuk campur kode bahasa yang ditemukan penulis dalam percakapan I.

(II/1) (I/3) Ibu Leni : Mungkin masib nak ruang kepala sekolah. Mot kileak au

'Mungkin masih di ruang kepala sekolah. Tunggu sebentar'

\section{(II/2) (I/9) Orang tua murid : Ini bu, pas foto ngen fotokopi KK \\ Ini bu, pas foto dan fotokopi'}

Data di atas penutur menggunakan bahasa Indonesia dengan memasukkan unsur bahasa Rejang yaitu nak berarti di. Data (II/1) (I/3) dikembalikan menjadi kalimat dalam bahasa Indonesia Mungkin masih di ruang kepala sekolah. Tunggu sebentar ya. Data (II/2) (I/9) kata ngen berarti dengan, dikembalikan menjadi kalimat dalam bahasa Indonesia Ini bu, pas foto dengan fotokopi $K K$. Terjadinya campur kode bahasa pada data tersebut disebabkan karena penutur terbiasa menggunakan bahasa Rejang dalam berkomunikasi sehari-hari. Hal ini yang menyebabkan penutur memasukkan unsur bahasa Rejang dalam bahasa Indonesia sehingga lawan tutur memahami maksud penutur. Demikian data di atas merupakan bentuk campur kode bahasa Rejang ke dalam bahasa Indonesia.

Campur kode kata dalam bahasa dalam bahasa Melayu Bengkulu pada percakapan VI. Percakapan VII yaitu percakapan antara Dina dan Riska yang merupakan satu Program Studi. Di ruangan kelas VII. Riska merupakan mahasiswa KKN yang sedang meneliti di SMPN 8 Bengkulu Tengah berumur 21 tahun sehari-hari menggunakan bahasa Melayu Bengkulu. Data (II/12) (VII/10) mengenai kondisi siswa di SMP N 8 Bengkulu Tengah yang kurang tertib. 
(II/12) (VII/10) Riska : : Iyo mbak. tapi cak ini lah

'Iya mbak.tapi seperti inilah'

Data di atas penutur menggunakan bahasa Indonesia dengan memasukkan bahasa Melayu Bengkulu yaitu cak berarti seperti. Data (II/12) (VII/10) dapat dikembalikan menjadi kalimat dalam bahasa Indonesia Iya mbak tapi seperti inilah. Terjadinya campur kode bahasa pada data di atas disebabkan karena penutur yang dalam kesehariannya dalam berkomunikasi sudah terbiasa menggunakan bahasa Melayu Bengkulu. Hal ini karena penutur berasal dari kota Bengkulu. Demikian data di atas merupakan bentuk campur kode masuknya unsur bahasa Melayu Bengkulu ke dalam bahasa Indonesia.

Campur kode kata dalam bahasa Inggris pada percakapan V. Percakapan $\mathbf{V}$ yaitu percakapan antara ibu Leni dan ibu Vivi tentang laporan kehadiran. Peristiwa ini terjadi pada tanggal 20 Juli 2019. Ibu Vivi adalah kepala Tu dan berumur 29 tahun sehari-hari menggunakan bahasa Rejang.

(II/13) (V/4) Ibu Vivi $\quad$ : Ya udah print 2 rangkap ajo. Takutny kelak yang 1 itu hilang masih ado arsipnya

'Ya sudah print rangkap 2 saja. Takutnya nanti yang 1 hilang masih ada arsipnya'

Data di atas penutur menggunakan bahasa Indonesia dengan memasukkan bahasa Inggris dan bahasa Indonesia yaitu print. Data (II/13) (V/4) dapat dikembalikan menjadi kalimat dalam bahasa Indonesia Ya sudah print dua rangkap saja. Takutnya bilang yang satu bilang masib ada arsipnya. Terjadinya campur kode bahasa pada data di atas disebabkan karena penutur tidak menemukan padanan kata yang tepat dalam bahasa Indonesia . Demikian data di atas merupakan bentuk campur kode masuknya unsur bahasa Inggris ke dalam bahasa Indonesia.

Campur kode kata dalam Jawa pada percakapan IX. Percakapan IX yaitu percakapan antara Siska dan ibu Eka dan guru Desmi terjadi di kantin sekolah pada saat istirahat. Topik pertemuan ibu Eka bertanya kepada Siska. Ibu Eka merupakan guru IPA terpadu sekalian ibu kantin berumur 35 tahun sehari-hari menggunakan bahasa Jawa.

(II/19) (IX/17) Ibu Eka : Wes lah. Semoga

cepat selesai.

'Oke lah. Semoga cepat selesai'

Data di atas penutur memasukkan unsur bahasa Jawa ke dalam bahasa Melayu Bengkulu yaitu weslah berarti okelah. Data (II/19) (IX/17) dapat dikembalikan menjadi kalimat dalam bahasa Indonesia Okelah. Semoga cepat selesai. Campur kode kata yang terjadi disebabkan karena penutur sehari-hari terbiasa menggunakan bahasa Jawa. Demikian data di atas merupakan bentuk campur kode kata masuknya unsur bahasa Melayu Bengkulu ke dalam bahasa Indonesia dan masuknya Unsur bahasa Jawa ke dalam bahasa Indonesia.

\section{B. Frasa}


Campur kode dalam penggunaan bahasa tataran frasa yang dimaksud adalah masuknya unsur-unsur bahasa lain selain bahasa-bahasa utama. Campur kode frasa terdiri atas campur kode frasa bahasa Rejang dan bahasa Jawa.

Campur kode dalam bahasa Rejang terdapat pada percakapan VI. Percakapan VI yaitu percakapan Pak Samson, Ibu Asma kepada siswa untuk membersihkan selokan. Topik pembicaraan mengenai kebersihan sekolah. Ibu Asma merupakan office girl berumur 30 tahun sehari-hari menggunakan bahasa Rejang.

(III/2) (VI/4) Ibu Asma : Bersihkan ini dulu.

be malua be

'Bersihkan ini dulu. Nanti alirkannya'

Data di atas penutur menggunakan bahasa Indonesia dengan memasukkan bahasa Rejang yaitu be malua be berarti alirkan nanti. Data (III/2) (VI/4) dapat dikembalikan menjadi kalimat dalam bahasa Indonesia Bersibkan ini dulu. Alirkan nanti. Terjadinya campur kode bahasa pada data tersebut disebabkan karena penutur terbiasa menggunakan bahasa Rejang dalam berkomunikasi sehari-hari. Hal ini yang menyebabkan penutur memasukkan unsur bahasa Rejang dalam bahasa Indonesia sehingga lawan tutur memahami maksud penutur. Demikian data di atas merupakan bentuk campur kode bahasa Rejang ke dalam bahasa Indonesia.

Campur kode dalam bahasa Jawa terdapat pada percakapan XII . Percakapan XII yaitu ibu Wiwik, ibu Nunik dan ibu Wesi mengenai ibu Wiwik akan menggantikan ibu Ratna yang sedang cuti. Topik pembicaraan mengenai pergantian guru. Ibu Nunik merupakan guru mata pelajaran Matematika berumur 32 tahun sehari-hari menggunakan bahasa Jawa.

(III/6) (XII/5) Ibu nunik : Lah, kenapa ambilnya sama bapak ? ora iso, seharusnya dia yang gaji kamu. 'Lah, kenapa ambilnya sama bapak? Tidak bisa, seharusnya dia yang gaji Kamu'

(III/7) (XII/7) Ibu Nunik : Ngaklah Wik.

Sakarap wae, nyuruh orang gantikan ngajar tapi ngak digaji 'Tidaklah Wik. Semaunya saja, minta gantikan tapi tidak digaji'

Data di atas penutur menggunakan bahasa Indonesia dengan memasukkan bahasa Jawa yaitu ora iso itu berarti tidak bisa itu dan sakarep wae berarti semannya saja. Data (III/6) (XII/5) dapat dikembalikan menjadi kalimat dalam bahasa Indonesia Kenapa ambilnya sama bapak? Tidak bisa itu, seharusnya dia yang gaji kamu. Data (III/7) (XII/7) dikembalikan menjadi kalimat dalam bahasa Indonesia Tidaklah Wik. Semaunya saja mau digantikan tapi tidak man gaji orang. Terjadinya campur kode bahasa pada data tersebut disebabkan karena ketidaksengajaan penutur memasukkan unsur bahasa Jawa. Hal ini karena penutur terbiasa menggunakan bahasa Jawa dalam sehari-hari. Demikian data di atas merupakan bentuk campur kode masuknya unsur bahasa Jawa ke dalam bahasa Indonesia.

\section{Klausa}


Peristiwa campur kode dalam penggunaan bahasa tataran klausa yang dimaksudkan adalah masuknya unsur klausa pada bahasa utama komunikasi di lingkungan SMPN 8 Bengkulu Tengah. Campur kode klausa ini masuknya unsur bahasa Rejang ke dalam bahasa Indonesia terdapat pada percakapan III.

Percakapan III yaitu percakapan antara Ibu Leni dan Bapak Rudi tentang pembuatan surat resmi. Percakapan di atas terjadi diruang TU antara pak Rudi dan ibu Leni yang membicarakan mengenai nomor surat yang akan ditulis pak Rudi pada surat pengantar pindahan anaknya.

(IV/3) (III/2) Ibu Leni : Surat apa pak?

surat pengantar? Kileak pak, uku mesoak kertas ku kileak pak.

'Surat apa pak? Surat pengantar. Sebentar pak, aku carikan kertas aku dulu pak'

Data di atas penutur menggunakan bahasa Indonesia dengan memasukkan bahasa Rejang yaitu Kileak pak, uku mesoak kertas ku kileak pak berarti sebentar pak. Akau carikan kertas aku dulu pak. Data (IV/3) (III/2) dapat dikembalikan menjadi kalimat dalam bahasa Indonesia Surat apa pak? Surat pengantar? Sebentar ya pak, aku carika kertas aku dulu pak. Terjadinya campur kode bahasa pada data tersebut disebabkan karena penutur terbiasa menggunakan bahasa Rejang dalam berkomunikasi sehari-hari. Hal ini yang menyebabkan penutur memasukkan unsur bahasa Rejang dalam bahasa Indonesia sehingga lawan tutur memahami maksud penutur. Demikian data di atas merupakan bentuk campur kode bahasa Rejang ke dalam bahasa Indonesia.

\section{PENUTUP}

Berdasarkan hasil penelitian yang telah dideskripsikan di atas, dapat disimpulkan bahwa campur kode bentuk kata yaitu campur kode kata dalam bahasa Rejang, bahasa Melayu Bengkulu, bahasa Inggris dan bahasa Jawa. Campur kode bentuk frasa yaitu campur kode frasa bahasa Rejang dan bahasa Jawa. Campur kode bentuk klausa yaitu campur kode klausa bahasa Rejang. Adapun faktor-faktor yang melatarbelakangi yaitu sikap penutur atau non kebahasaan dan kebahasaan.

Disarankan pada penelitian selanjutnya untuk melanjutkan wujud campur kode bentuk baster, perulangan, dan idiom yang belum diteliti oleh penulis. Menunjukkan sikap positif berbahasa Indonesia.

\section{DAFTAR PUSTAKA}

Aslinda dan Leni Syafyahya. 2007. Pengantar Sosiolinguistik. Bandung: Refika Aditama.

Chaer, Abdul dan Leonie Agustina. 2004. Sosiolinguistik. Jakarta: Rineka Cipta.

Nababan, P. W. J. 1991. Sosiolinguistik Suatu Pengantar. Jakarta: PT Gramedia Pustaka Utama.

Nugroho, Adi. 2011. Alib Kode dan Campur Kode Pada Komunikasi Guru-Siswa di SMA Negeri 1 Wonosari Klaten. Yogyakarta: Universitas Negeri Yogyakarta. 
Nugroho, Pungki. 2012. Analisis Penggunaan Alih Kode dan Campur Kode Pada Guru Bahasa Indonesia di SMP Negeri 2 Mantingan. Surakarta: Universitas Muhammadiyah Surakarta.

Saputra, Angga. 2015. Campur Kode pada Kata Sambutan Acara Resepsi Pernikahan masyarakat Serawai. Bengkulu: Universitas Bengkulu.

Sari, I.F.M. 2016. Skripsi. Kajian Alih Kode dan Campur Kode dalam Tuturan Masyarakat Kelurahan Jalan baru Kecamatan Curup Kota Kabupaten Rejang Lebong. Bengkulu: Universitas Bengkulu.

Sumarsono dan Paina Partana. 2007. Sosiolinguistik. Yogyakarta: Pustaka Belajar.

Suwito. 1983. Pengantar Awal Sosiolinguistik. Surakarta: Henari Offset Solo.

UU Nomor 24 tahun 2009 pasal 29 ayat 1. Bahasa Pengantar dalam Pendidikan Nasional: Bahasa Indonesia. 